\title{
NUP98/HOXA9 Fusion Gene
}

National Cancer Institute

\section{Source}

National Cancer Institute. NUP98/HOXA9 Fusion Gene. NCI Thesaurus. Code C99440.

A fusion gene that results from a chromosomal translocation $t(7 ; 11)(\mathrm{p} 15 ; \mathrm{p} 15)$ which fuses the first half of the NUP98 gene to the 3' portion of the HOXA9 gene. This rearrangement is associated with acute myeloid leukemia. 